\title{
Roles of Carotenoids in Invertebrate Immunology
}

\author{
Karsoon Tan ${ }^{1,2,3}$, Hongkuan Zhang ${ }^{1,2,3}$, Leong-Seng Lim ${ }^{4}$, Hongyu Ma ${ }^{1,2,3}$, \\ Shengkang $\mathrm{Li}^{1,2,3}$ and Huaiping Zheng ${ }^{1,2,3 *}$
}

${ }^{1}$ Key Laboratory of Marine Biotechnology of Guangdong Province, Institute of Marine Sciences, Shantou University, Shantou, China, ${ }^{2}$ Mariculture Research Center for Subtropical Shellfish \& Algae of Guangdong Province, Shantou, China, ${ }^{3}$ STU-UMT Joint Shellfish Research Laboratory, Shantou University, Shantou, China, ${ }^{4}$ Borneo Marine Research Institute, University Malaysia Sabah, Kota Kinabalu, Malaysia

\section{OPEN ACCESS}

Edited by:

Laurel J. Gershwin, University of California, Davis,

United States

Reviewed by:

Caroline V. Palmer, University of Plymouth,

United Kingdom

Annalisa Pinsino,

Istituto per la Ricerca e L'Innovazione

Biomedica (CNR), Italy

Edwin Cooper

University of California, Los Angeles, United States

*Correspondence: Huaiping Zheng

hpzheng@stu.edu.cn

Specialty section:

This article was submitted to

Comparative Immunology,

a section of the journal

Frontiers in Immunology

Received: 20 September 2019 Accepted: 11 December 2019 Published: 17 January 2020

Citation:

Tan K, Zhang H, Lim L-S, Ma H, Li S and Zheng $H$ (2020) Roles of Carotenoids in Invertebrate Immunology.

Front. Immunol. 10:3041. doi: 10.3389/fimmu.2019.03041
Carotenoids are biologically active pigments that are well-known to enhance the defense and immunity of the vertebrate system. However, in invertebrates, the role of carotenoids in immunity is not clear. Therefore, this study aims to review the scientific evidence for the role of carotenoids in invertebrate immunization. From the analysis of published literatures and recent studies from our laboratory, it is obvious that carotenoids are involved in invertebrate immunity in two ways. On the one hand, carotenoids can act as antioxidant enzymes to remove singlet oxygen, superoxide anion radicals, and hydroxyl radicals, thereby reducing SOD activity and reducing the cost of immunity. In some organisms, carotenoids have been shown to promote SOD activity by up-regulating the expression of the $Z n C U S O D$ gene. Carotenoids, on the other hand, play a role in the expression and regulation of many genes involved in invertebrate immunity, including thioredoxins (TRX), peptidoglycan recognition receptor proteins (PGRPs), ferritins, prophenoloxidase (ProPO), vitellogenin (Vg), toll-like receptor (TLRs), heat shock proteins (HSPs), and CuZnSOD gene. The information in this review is very useful for updating our understanding of the progress of carotenoid research in invertebrate immunology and to help identify topics for future topics.

Keywords: carotenoids, invertebrate, immunity, antioxidant, immunostimulant, review

\section{INTRODUCTION}

Vertebrates possess both innate and adaptive immune systems, of which the adaptive immune system has many specialized cells and molecules that interact in a particular way (1). Unlike vertebrates, the only line of defense for invertebrates is innate immune system (2). The response of innate immunity to infection or injury is by releasing highly reactive oxygen and nitrogen species (ROS and RNS) at the focal point, which leads to immune cost and host tissues destruction (immunopathology) $(3,4)$. The cost of immunity is the operating cost of the immune response, which reduces the availability of resources for other physiological functions $(5,6)$. Being lack of specific immunity, both enzymes and non-enzymatic antioxidants play a crucial role in immunity of invertebrates (7). The main enzymes in the innate immune system include catalase (CAT), superoxide dismutase (SOD), glutaredoxins, thioredoxins (TRX), peroxiredoxins (PRXs), and GSH-Px (8). Major non-enzymatic antioxidants, including carotenoids, polyunsaturated fatty acids (PUFA), uric acid, vitamins (vitamins $\mathrm{C}$ and E) and GSH, and a tripeptide (L-g-glutamyl-L-cysteinyl-L-glycine), comprise a thiol (sulfhydryl) group $(8,9)$. 
Carotenoids, also known as tetraterpenoids, are responsible for colorless, red, orange, and yellow pigments in plants, insects, crustaceans, fish, and birds (10-12). Carotenoids are produced by plants, algae, and certain microbes (10), with basic structural units of isopentenyl (IPP) and dimethylallyl diphosphate (DMAPP) (Figure 1). Carotenoids are biologically active pigments that have beneficial effects on the body conditions (13), which increase the efficiency of immune responses and stimulate innate immunity components $(14,15)$. Furthermore, as part of the integrated antioxidant system (16, 17), high carotenoid content in an organism enhances immunity without increasing the associated costs of immunity by aiding endogenous enzymes (e.g., catalase, superoxide dismutase) and detoxifying free radicals produced during immune activity (1821). In general, animals cannot biosynthesize carotenoids de novo, so they obtain carotenoids either directly from food or partially modified through metabolic reactions (22).

On the other hand, Royet et al. (23) revealed a series of pattern recognition receptors (PRR), especially peptidoglycan recognition proteins (PGRPs), which are highly conserved in evolution and can help the innate immune system recognizing pathogens through their unique cell wall component, peptidoglycan (PGN). The ability of carotenoids in regulating the transcription of various PRR genes has been extensively studied in vertebrates, particularly in humans $(24,25)$. Moreover, the immune response of invertebrates to infectious diseases has received considerable attention because many of them are important species in fisheries and aquaculture, while others are critical to the structure and function of ecosystems (26-39).

To date, Maoka (22), Liaaen-Jensen (40, 41), Matsuno (42, 43), and Matsuno and Hirao (44) have reviewed carotenoid species in invertebrates. All of these published reviews have focused on the emergence of specific carotenoid groups in invertebrates, but the links between carotenoids and invertebrate immunity have received relatively little attention. Recently, there have been more and more reports on the roles of carotenoids in invertebrate immunity in time-series observations and laboratory experiments $(26,35-38,45-51)$, but the information is not well-collated. Therefore, in this review, we summarized the currently available data on the effects of carotenoids on invertebrate immunity. In particular, we reviewed the role of carotenoids in antioxidant system, immune system, and

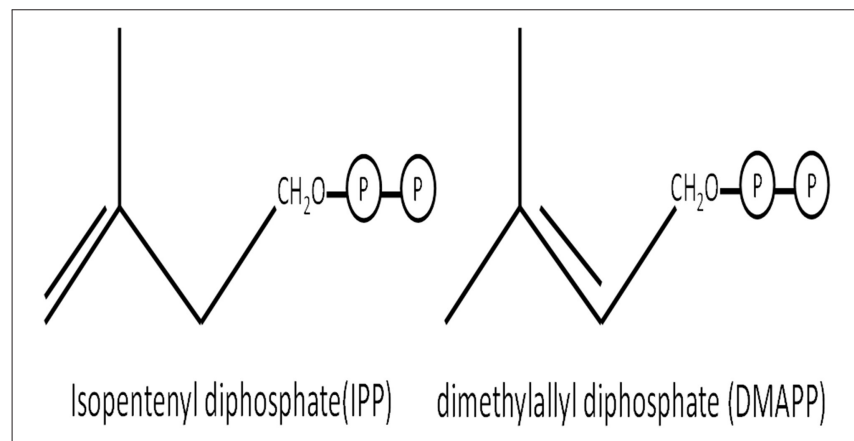

FIGURE 1 | Basic blocks of carotenoids. unfavorable environmental tolerance of invertebrates. To the best of our knowledge, this paper represents the first review reviewing the role of carotenoids in invertebrate immunity. This information is very useful for updating our understanding of the progress of the carotenoid research in invertebrate immunology and for identifying future research topics.

\section{INVERTEBRATE IMMUNE SYSTEM}

Invertebrates account for $97 \%$ of animal diversity and can actually be found in any environment. In general, a range of cellular and humoral defenses are involved in protecting invertebrates from pathogens that manage to penetrate their exoskeleton/cuticle or alimentary canal to internal tissues. Cells associated with innate immunity include hemocytes (circulating and sessile blood cells) and various other cell types, including fat body, coelomocytes, hepatopancreas, and gills in insects, earthworm, molluscs, and crustaceans, respectively (52-55). If the pathogens manage to penetrate its external barrier, the blood cells present in the body cavity can destroy the tiny invaders such as bacteria, fungi, protozoans, and viruses by phagocytosis, and encapsulate the multicellular parasites by encapsulation, thereby isolating invaders from the host (54-56).

In the humoral defense of invertebrates, invaders such as bacteria and fungi are eliminated by antimicrobial peptides (AMPs). In insects (Drosophila) and shrimps, several distinct AMP forms are synthesized by the fat body and hemocytes, respectively (57). The prophenoloxidase (proPO) enzyme cascade based on phenoloxidase (PO) enzyme activity is one of the effective effectors of humoral responses. After a stepwise proteolytic activation, the PO enzyme is responsible for the production of melanin, as well as the release of quinonederived metabolites and reactive oxygen species. These chemicals are not only destructive to pathogens, but also have cytotoxic oxidative effects on the basic host cell components $(58,59)$. Matova and Anderson (60) reassessed the importance of cellular (phagocytosis) and humoral (AMP) defense in Drosophila. The results indicated that the double mutants of Drosophila larvae contain negligible circulating hemocytes, but high levels of AMPs did not survive from opportunistic bacterial or fungal infection (60).

Invertebrates are a very heterogeneous group of animals (about 1.3 million species). This wide distribution indicates that innate immune defense mechanisms of invertebrates enable them to adapt and survive in diverse environments. In fact, in the same host, different bacterial strains or species may trigger different immune effectors, leading to different immune responses (61). It is worth noting that recent studies in sea urchin have shown that titanium dioxide nanoparticles can temporarily suppress the inflammatory-related gene transcription and boost metabolic activity of antioxidants (62-64). The innate immune memory in invertebrates such as bivalves (65), gastropods (66), insect (67), and crustaceans (68) is established by re-programming of innate immune functions after being induced by a stimulus, which will result either in decreased reactivity (tolerance) or increased responsiveness (potentiation) to a subsequent challenge. In both 
cases, the main purpose of establishing innate immune memory is to better defend and regulate its functional immune phenotype in response to subsequent stimuli.

\section{CAROTENOIDS}

Carotenoids have received considerable attention for their beneficial effects on human health and their wide range of biotechnological applications $(11,69)$. Carotenoids have been reported to enhance the immune system (70), repair DNA damage (51), and prevent in vitro auto-oxidative damage of human lymphocytes (71), thereby reducing the risk of various diseases $(72,73)$.

Some invertebrates, including insects, polyplacophora, echinoderms, gastropods, bivalves, and cephalopods, are rich in carotenoids $(35,48,49,74)$. The accumulation of carotenoids in invertebrates is tissue specific, and the highest total carotenoids content (TCC) is usually observed in the gonads, as carotenoids are essential for invertebrate reproduction (74). Zheng et al. (74) have shown that the accumulation of TCC in invertebrates, particularly bivalve, noble scallops Chlamys nobilis, is affected by genetic factors, which are controlled by genes associated with carotenoid absorption, such as SRB-like-3 (75) and StAR-like-3 (76).

Chemically, the polyene backbone consists of a series of conjugated $\mathrm{C}=\mathrm{C}$ bonds. This particular feature is responsible for the main biological functions of carotenoids associated with antioxidant properties, where dietary carotenoids provide a degree of antioxidant protection for cells, tissues, and other structures $(24,51,77)$, thereby reducing self-harming caused by cytotoxic chemicals released by immunological activity
(78, 79). Moreover, carotenoids can enhance the defense capability and immune competence of various animal systems by up-regulating the expression levels of immune-related genes $(35-38,80)$.

\section{ROLES OF CAROTENOIDS IN INVERTEBRATE ANTIOXIDANT SYSTEM}

During the inflammatory response, the release of excessive cytotoxic chemicals [highly reactive oxygen species (ROS) and nitrogen species (RNS)] not only destroys pathogens and parasites, but also damages the tissues and organs of the host itself (immunopathology) (3). These biochemical and physiological damages may eventually lead to disease by impairing metabolism, causing oxidative damage to lipids, proteins, and nucleic acids $(4,81-83)$ (Figure 2). In addition, if the damaged tissues are not fully recovered and that homeostasis is not restored, it will further develop into a chronic condition, such as an increase in rates of morbidity and mortality in the elderly (84-86). Antioxidant defense systems in invertebrates play a vital role in controlling the amount of circulating cytotoxic ROS and RNS. This system comprises three key antioxidant enzymes, including superoxide dismutase (SOD), catalase (CAT), and glutathione peroxidase (GP), which in turn participate in the detoxification of superoxide radicals: SOD converts superoxide into hydrogen peroxide, which is then detoxified into water and oxygen by CAT and GP (17, 87). It has been reported that the structure and function of SOD are well-conserved in diverse organisms including marine invertebrates (88).

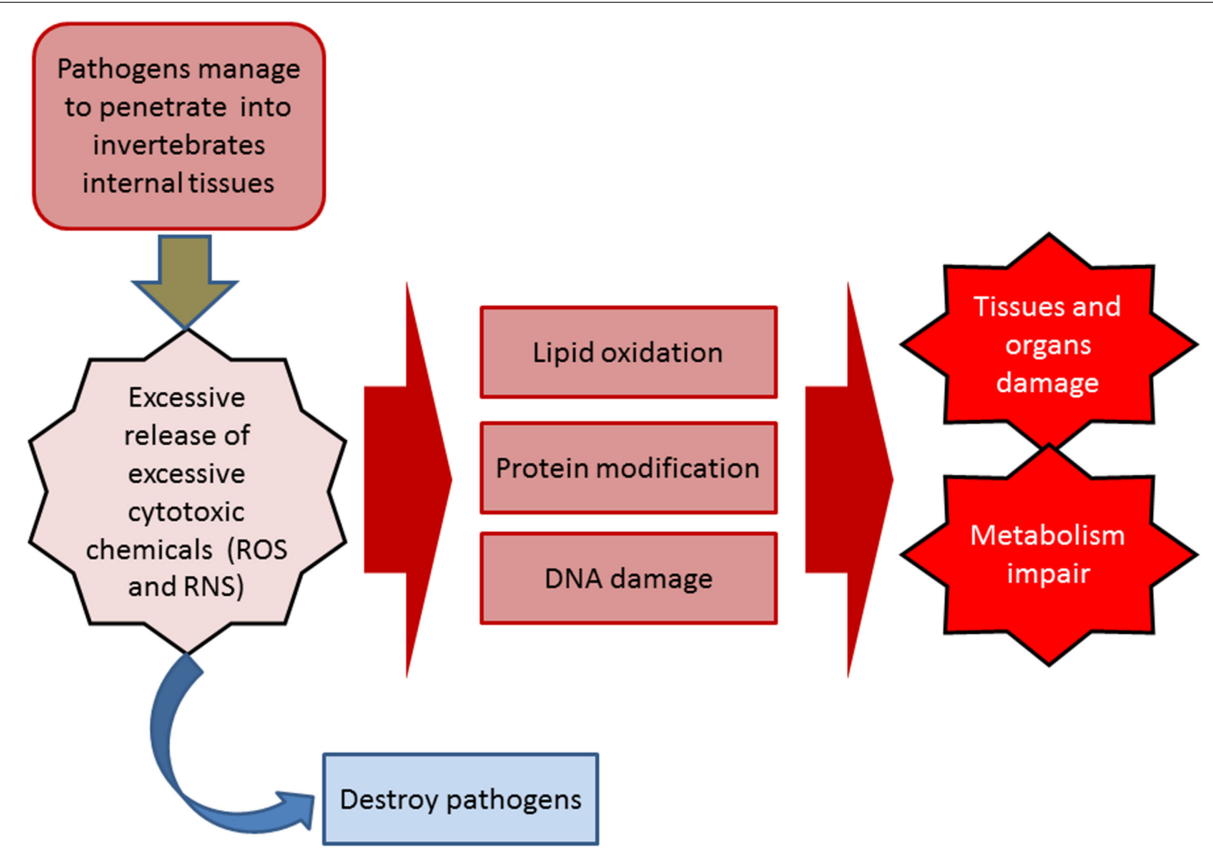

FIGURE 2 | Inflammatory response in innate immunity. 
Scenario 1: Carotenoids reduce the relative activity of SOD (by scavenging some superoxide) and increase the relative activity of CAT (by producing more hydrogen peroxide). Invertebrate models: Tenebrio molitor, Gammarus pulex, Anadara inaequivalvis

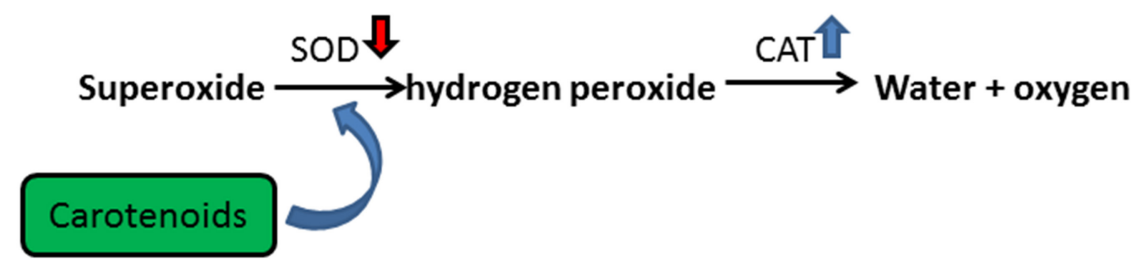

\section{Scenario 2: Carotenoids stimulate the activity of SOD by up-regulating the expression of CUZnSOD gene. Invertebrate models: Chlamys nobilis}

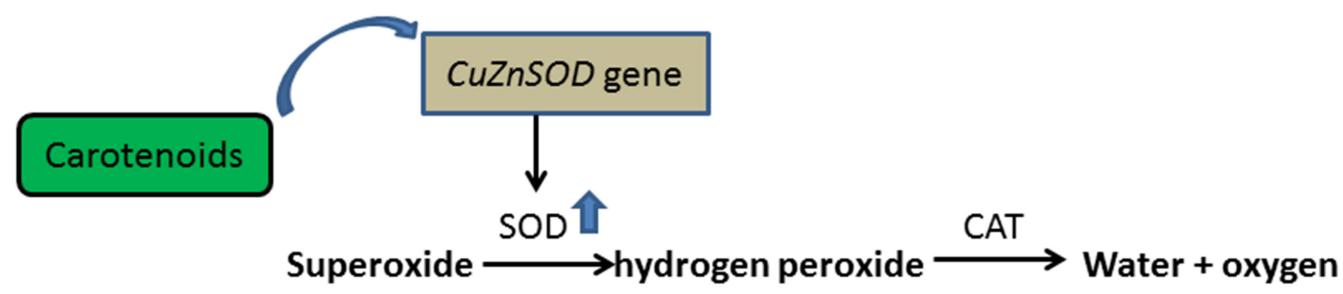

FIGURE 3 | Roles of carotenoids in invertebrate antioxidant system.

In invertebrates, carotenoids are involved in the antioxidant defense system in two ways (Figure 3). On the one hand, carotenoids may reduce the relative activity of antioxidant enzymes by taking over their actions, thereby reducing the cost of immunity $(20,21)$. Carotenoids are effective in scavenging singlet oxygen $\left({ }^{1} \mathrm{O}_{2}\right)(89)$, superoxide anion radicals (SOAR), and hydroxyl radicals (OH•) (90). Tsushima et al. (91) reported that the $\beta$-carotene supplementation in cultured sea urchin significantly increased carotenoids levels in the gonads, thereby enhancing the immunological activity of sea urchins and was associated with higher reproduction and survival of sea urchin larvae (92). Invertebrates that store large amounts of carotenoids in tissues have a higher competitive relationship with the cellular enzymatic antioxidant (AO) complexes for the corresponding substrates. Dhinaut et al. (48) used the mealworm beetle Tenebrio molitor as a biological model of invertebrates, demonstrating that lifetime food supplementation with carotenoids (particularly astaxanthin) can prevent immunopathology through immunosuppression. Moreover, Babin et al. (49) revealed that the presence of considerable concentration of carotenoids in amphipod crustacean Gammarus pulex reduced SOD activity, in which carotenoids take over the role of SOD, first acting on the detoxification chain of superoxide radicals and producing hydrogen peroxide. Then, a high concentration of hydrogen peroxide promotes CAT activity, acting in second in the detoxification chain. A similar observation has been reported in the blood cockles, Anadara inaequivalvis, in which 1.7 to 2.9 times lower SOD activity and an elevated content of reduced glutathione were recorded in tissues with high carotenoid content (50). In addition, carotenoids can reduce the susceptibility of single-stranded nucleic acid breaks in cell lines to oxidative damage ( $\left.100 \mu \mathrm{mol} \mathrm{H}_{2} \mathrm{O}_{2} / \mathrm{L}, 5 \mathrm{~min}, 4^{\circ} \mathrm{C}\right)$, either by scavenging DNA-damage free radicals or regulating DNA repair mechanisms (51).

On the other hand, besides a free radical scavenger, carotenoids have also been shown to stimulate the activity of antioxidant enzymes in invertebrates (38), thereby enhancing the detoxification efficacy of immunological activity. It has been reported that in noble scallops, $C$. nobilis, CuZnSOD gene is upregulated by carotenoid to enhance detoxification (38). However, due to the continuous contact of gills with water, the upregulation of $C u Z n S O D$ transcript is tissue-specific, with the highest expression levels in gills (93). In addition, it is evident from clinical studies that a high-fat diet with high carotenoid content is associated with an increase in CuZnSOD, thereby increasing the expression of CuZnSOD and protecting tissue cells from oxidative damage (94). In both cases, carotenoids can improve the detoxification of free radicals and reduce the costs associated with oxidative stress.

\section{ROLE OF CAROTENOIDS AS IMMUNOSTIMULANT IN INVERTEBRATES}

Carotenoids enhance the defense and immunity of various animal systems $(18,95)$. For instance, dietary trials in amphipod 
TABLE 1 | Gene expression regulations by carotenoids under different stressors.

\begin{tabular}{|c|c|c|c|}
\hline Gene & $\begin{array}{l}\text { Up-regulated gene } \\
\text { expression (times) }\end{array}$ & Stressors & References \\
\hline Thioredoxins (TRX) & $1.18-1.76$ & Vibrio parahaemolyticus & (35) \\
\hline PGRP gene & $1.60-1.80$ & V. parahaemolyticus and polyinosinic polycytidylic acid (Poly I: C) & Unpublished data \\
\hline Ferritins & $1.20-1.90$ & V. parahaemolyticus & $(47)$ \\
\hline $\begin{array}{l}\text { Prophenoloxidase } \\
\text { (ProPO) }\end{array}$ & $1.07-1.21$ & Bacterial infection & $(18,39)$ \\
\hline Vitellogenin (Vg) & $1.60-2.78$ & NiL & (36) \\
\hline $\begin{array}{l}\text { Toll-like Receptor } \\
\text { (TLRs) }\end{array}$ & $1.10-4.00$ & V. parahemolyticus and lipopolysaccharide and Poly I:C & $(37)$ \\
\hline $\begin{array}{l}\text { Heat shock } \\
\text { proteins (HSPs) }\end{array}$ & $1.20-2.00$ & Heat shock challenge at $32^{\circ} \mathrm{C}$ & $(26,45)$ \\
\hline CuZnSOD gene & $1.20-2.20$ & lower temperature stress & (38) \\
\hline
\end{tabular}

crustacean G. pulex demonstrated that supplementation of astaxanthin resulted in broad stimulation of innate immunity to gammarid and increase resistance to microbial infection (18). Similarly, Kumar et al. (95) revealed that dietary supplementation of astaxanthin was associated with an increase in phenoloxidase activity and total hemocyte count in the giant freshwater prawn Macrobrachium rosenbergii. In the same species, the injection of astaxanthin also increased the total hemocyte count and survival rate under the challenge of the pathogenic bacterium Lactococcus garvieae (96). The higher immunity of invertebrates containing significant amounts of carotenoids can be partly explained by the fact that carotenoids regulate gene expression of several immune-related genes, in particular thioredoxin-like protein (TRX) gene (35), peptidoglycan recognition receptor proteins (PGRPs) gene (Unpublished data), ferritin genes (47), prophenoloxidase (ProPO) gene $(18,39)$, vitellogenin (Vg) gene (36), toll-like receptor (TLRs) gene (37), Heat shock proteins (HSP70 and HSP 90) (26, 45, 97), and CuZnSOD gene (38) (Table $\mathbf{1}$ ).

Thioredoxins (TRXs) contain a dithiol/disulfide active site (CGPC) and are the major cellular protein disulfide reductase in the thioredoxin system (98). TRXs have been shown to be involved in the immunity of marine invertebrates, including Apostichopus japonicas (99), Ruditapes philippinarum (100), Litopenaeus vannamei (101), and Haliotis discus discus (102). Up-regulation of TRX gene expression in bivalves has been demonstrated under bacteria stress $(35,103)$. Recent studies on the effects of Vibrio parahaemolyticus challenge on two polymorphic scallops with different total carotenoid content (golden and brown scallops; the total carotenoid content of golden scallops is significantly higher than that of brown scallops) reveal that the expression level of TRX is up-regulated in the golden scallops by 1.18 to 1.76 times relative to the brown scallops, indicating that carotenoids up-regulated the expression of TRX gene under bacterial challenge (35).

$\mathrm{Vg}$ is a precursor of vitellin $(\mathrm{Vn})$ in egg yolk, a major source of energy in embryonic development (104). Vg is expressed in females of nearly all oviparous species, including amphibians, fish, birds, reptiles, most invertebrates, and monotremes (105,
106). Moreover, $\mathrm{Vg}$ is a non-polar molecule carrier that transfers lipids and carotenoids to oocytes (107). The role of $\mathrm{Vg}$ in host immune defense against bacteria and viruses has been extensively studied in many oviparous animals, including marine bivalve Patinopecten yessoensis, in which $\mathrm{Vg}$ has antibacterial activity (108). Zhang et al. (36) demonstrate that the Vg transcription level in the ovary of noble scallop C. nobilis is directly proportional to the total carotenoid content, indicating that Vg expression is up-regulated by carotenoids.

PGRPs are a group of pattern recognition receptors (PRRs) that are conserved from invertebrates to vertebrates. However, PGRPs function differently in innate immunity of invertebrates and vertebrates. In most invertebrates, PGRPs not only participate in multiple host defense processes, including hydrolysis of PGN and cell phagocytosis, but also play an important role in bacterial pathogen sensing $(109,110)$. For example, in bay scallops, PGRP is involved in the scallop immune response against gram-positive bacterial infections, primarily induced by bacterial PGN (109). In Solen grandis, both PGRP-S1 and PGRP-S2 are induced by pathogen-associated molecular patterns (PAMPs) and PGN (110), whereas in $C$. nobilis, the CnPGRP gene can be induced by V.parahaemolyticus, LPS, and Poly I:C. Interestingly, the presence of high total carotenoids content was associated with up-regulation of CnPGRP expression, particularly in the gills (1.8 times) and hepatopancreas (1.6 times) of C. nobilis under immunostimulant stress (unpublished data).

Ferritins are important iron-chelating proteins that play crucial roles in the iron-withholding defense system (111). These proteins are ubiquitous in a variety of organisms, including fungi, bacteria, invertebrates, plants, and vertebrates, and show several conserved features (112). High expression of cytosolic and secreted ferritin in invertebrates has been demonstrated to improve innate immune defense in invertebrates (113). Under bacterial challenge, the expression level of ferritins gene (upregulated by $1.20-1.90$ times) was positively correlated with total carotenoids content in $C$. nobilis, indicating that carotenoids up-regulated the expression of ferritins gene under bacterial stress (47). 
Pattern recognition receptors (PRRs) are a group of recognition proteins of the innate immune system associated with the detection of pathogen-associated molecular patterns (PAMPs) $(114,115)$. One type of PRR, TLRs, is an important transmembrane protein that connects innate immunity and adaptive immunity (116). TLRs detect microorganisms based on conserved PAMPs such as lipoproteins, PGNs, lipopolysaccharides (LPS), double-strand viral RNA, unmethylated bacterial CpG DNA, and many more (117). In non-mammalian vertebrates to invertebrates, many species have also been shown to have numerous TLRs (118). Invertebrate TLRs are mainly studied in bivalves such as Chlamys farreri (119), Mytilus galloprovincialis (120), Crassostrea gigas (121), Mya arenaria (122), the cephalopod Sepia officinalis (123), and Euprymna scolopes (124). Laboratory challenge tests on polymorphic scallops with $V$. parahemolyticus and LPS and Poly I:C showed that under the influence of carotenoids, CnTLR-1 transcripts were significantly up-regulated in the hemolymph (37).

Prophenoloxidase (ProPO) activation system plays an important role in initiating melanin synthesis by detecting microbial cell surface molecules such as PGNs or LPS in bacteria and $\beta$-1,3-glucans in fungi (125-127). Cornet et al. (39) found that both PO and total activity were positively correlated with carotenoid concentrations in the hemolymph of G. pulex population, highlighting the potential importance of dietary carotenoids in the evolution of investments in immune defense and their short-term up-regulation in G. pulex. Consistent with this up-regulation, dietary supplementation with carotenoids is associated with increased resistance to bacterial infections, further supporting the idea of stimulating the effects of carotenoids on immunity. Babin et al. (18) propose that this immunostimulation either requires the carotenoids in the hemolymph to reach a threshold level or that it needs to increase the level of carotenoids for a sufficiently long time. Unexpectedly, despite the enhanced immunological activity, gammarids fed on carotenoids did not suffer from additional immunity cost compared to control gammarids (18). Raising PO activity is likely beneficial in fighting pathogen attacks, but it is also known to be costly through autoreactivity (4). Therefore, this observation might indicate that dietary carotenoids help to reduce this cost, enabling individuals to raise their immune activity and resist infections more effectively.

\section{ROLE OF CAROTENOIDS IN INVERTEBRATE ENVIRONMENTAL TOLERANCE}

Immunity is strongly influenced by environmental conditions. Altered environmental conditions can directly affect immunity by changing the concentration and efficiency of cytokine receptors, cytokines, and cells of the immune response, or indirectly affecting immunity by inducing general stress responses (128). Carotenoids have increased the resistance of invertebrates to environmental stress factors such as low salinity (46) and heat stress $(26,38,45,97)$. Under low salinity stress, the SOD content and expression level of scallop serine protease inhibitor (SPI) gene were positively correlated with total carotenoids, indicating that carotenoids enhanced the resistance of C. nobilis to low salinity (46).

Heat shock proteins (HSPs) are composed of a group of highly conserved proteins that are widely found in prokaryotes and eukaryotes. They increase the resistance of organisms to stressors and maintain cellular homeostasis (129). HSP expression is rapidly up-regulated when organisms are exposed to hypoxia, high temperatures, heavy metals, pathogen invasions, starvation, or trauma $(130,131)$. The HSP90 synthesis has been shown to induce by external stress in various mollusks, such as $C$. farreri (132), Argopecten irradians (133), C. gigas (134), Haliotis discus hannai (135), R. philippinarum (136), and Hyriopsis cumingii (129). Recent studies have demonstrated that in a heat shock challenge at $32^{\circ} \mathrm{C}$ for $36 \mathrm{~h}$, HSP90 expression levels are higher (1.2 to 2.0 times) in $C$. nobilis with higher total carotenoids content (60 to $120 \mu \mathrm{g} / \mathrm{g}$ ) compared with common brown noble scallops with lower TCC (40 to $52 \mu \mathrm{g} / \mathrm{g}$ ) (97). In the same species, carotenoids can also up-regulate the expression of HSP70 by 2.0 to 12.0 times after $36 \mathrm{~h}$ of acute cold stress challenge in $8^{\circ} \mathrm{C} \mathrm{(26)}$ and acute heat stress challenge in $32^{\circ} \mathrm{C}(45)$.

Carotenoids also have shown to up-regulate the expression of CuZnSOD gene in mollusc under low temperature stress, and there was a strong positive correlation between total carotenoid content and the expression level of CuZnSOD gene in $C$. nobilis (38). Moreover, carotenoids can also enhance defense by participating in maintenance of membranes in a fluid state during low-temperature stress (137).

\section{CONCLUSION}

Evidence from analytical, biochemical, and molecular studies demonstrated that carotenoids play an important role in invertebrate immunity. Carotenoids not only actively scavenge singlet oxygen, superoxide anion radicals, and hydroxyl radicals, thereby reducing the cost of immunity, but also regulate the expression of immune-related genes. In this context, there are still some issues that need to be resolved. The exact mechanism by which carotenoids may reduce the cost of self-harm in immune responses remains to be tested. Moreover, the exact role of carotenoids in more invertebrate species remains to be studied.

\section{AUTHOR CONTRIBUTIONS}

KT performed the data analysis and drafted the manuscript. HZhe, HZha, L-SL, HM, and SL revised the draft.

\section{FUNDING}

The present study was financially supported by the National Key R\&D Program of China (2018YFD0901400), the National Natural Science Foundation of China (31872563), the China Modern Agro-industry Technology Research System (CARS-49), the Department of Education of Guangdong Province, China (2017KCXTD014 and 2018KQNCX073), and the Talented Young Scientist Program (MALAYSIA-19-002). 


\section{REFERENCES}

1. Hughes AL. Vertebrate immune system: evolution. Encycl Life Sci. (2006). doi: 10.1002/9780470015902.a0006125

2. Guan R, Mariuzza RA. Peptidoglycan recognition proteins of the innate immune system. Trends Microbiol. (2007) 15:127-34. doi: 10.1016/j.tim.2007.01.006

3. Pursall ER, Rolff J. Immune responses accelerate ageing: proofof-principle in an insect model. PLoS ONE. (2011) 6:e19972. doi: 10.1371/journal.pone.0019972

4. Sadd BM, Siva-Jothy MT. Self-harm caused by an insect's innate immunity. Proc R Soc B Biol Sci. (2006) 273:2571-4. doi: 10.1098/rspb.2006.3574

5. Siva-Jothy MT, Moret Y, Rolff J. Insect immunity: an evolutionary ecology perspective. Adv Insect Physiol. (2005) 32:1-48. doi: 10.1016/S0065-2806(05)32001-7

6. Ahmed AM, Baggott SL, Maingon R, Hurd H. The costs of mounting an immune response are reflected in the reproductive fitness of the mosquito Anopheles gambiae. Oikos. (2002) 97:371-7. doi: 10.1034/j.1600-0706.2002.970307.x

7. Song L, Wang L, Zhang H, Wang M. The immune system and its modulation mechanism in scallop. Fish Shellfish Immunol. (2015) 46:65-78. doi: 10.1016/j.fsi.2015.03.013

8. Birben E, Sahiner UM, Sackesen C, Erzurum S, Kalayci O. Oxidative stress and antioxidant defence. World Allergy Organ J. (2012) 5:9-19. doi: 10.1097/WOX.0b013e3182439613

9. Zhang B, Deng Z, Tang Y, Chen P, Liu R, Ramdath DD, et al. Fatty acid, carotenoid and tocopherol compositions of 20 Canadian lentil cultivars and synergistic contribution to antioxidant activities. Food Chem. (2014) 161:296-304. doi: 10.1016/j.foodchem.2014.04.014

10. Nisar N, Li L, Lu S, Khin NC, Pogson BJ. Carotenoid metabolism in plants. Mol Plant. (2015) 8:68-82. doi: 10.1016/j.molp.2014.12.007

11. Zhang J, Sun Z, Sun P, Chen T, Chen F. Microalgal carotenoids: beneficial effects and potential in human health. Food Funct. (2014) 5:413-25. doi: 10.1039/c3fo60607d

12. Yatsunami R, Ando A, Yang $Y$, Takaichi S, Kohno M, Matsumura $\mathrm{Y}$, et al. Identification of carotenoids from the extremely halophilic archaeon Haloarcula japonica. Front Microbiol. (2014) 5:100. doi: $10.3389 /$ fmicb. 2014.00100

13. Higuera-Ciapara I, Fe'lix-Valenzuela L, Goycoolea FM. Astaxanthin: a review of its chemistry and applications. Critic Rev Food Sci Nutr. (2006) 46:185-96. doi: 10.1080/10408690590957188

14. McGraw KJ, Ardia DR. Do carotenoids buffer testosterone-induced immunosuppression? an experimental test in a colourful songbird. Biol Lett. (2007) 3:375-8. doi: 10.1098/rsbl.2007.0190

15. Blount JD, Metcalfe NB, Birkhead TR, Surai PF. Carotenoid modulation of immune function and sexual attractiveness in zebra finches. Science. (2003) 300:125-7. doi: 10.1126/science.1082142

16. Møller AP, Biard C, Blount JD, Houston DC, Ninni P, Saino N, et al. Carotenoid-dependent signals: indicators of foraging efficiency, immunocompetence or detoxification ability? Avian Poultry Biol Rev. (2000) 11:137-59.

17. Felton GW, Summers CB. Antioxidant systems in insects. Arch Insect Biochem Physiol. (1995) 29:187-97. doi: 10.1002/arch.940290208

18. Babin A, Biard C, Moret Y. Dietary supplementation with carotenoids improves immunity without increasing its cost in a crustacean. Am Nat. (2010) 176:34-241. doi: 10.1086/653670

19. Costantini D. Oxidative stress in ecology and evolution: lessons from avian studies. Ecol Lett. (2008) 11:1238-51. doi: 10.1111/j.1461-0248.2008. 01246.x

20. Wang YJ, Chien YH, Pan CH. Effects of dietary supplementation of carotenoids on survival, growth, pigmentation, and antioxidant capacity of characins, Hyphessobrycon callistus. Aquaculture. (2006) 261:641-8. doi: 10.1016/j.aquaculture.2006.08.040

21. Chien $\mathrm{YH}, \mathrm{Pan} \mathrm{CH}$, Hunter B. The resistance to physical stresses by Penaeus monodon juveniles fed diets supplemented with astaxanthin. Aquaculture. (2003) 216:177-91. doi: 10.1016/S0044-8486(02)00056-X

22. Maoka T. Carotenoids in marine animals. Marine Drugs. (2011) 9:278-93. doi: $10.3390 / \mathrm{md} 9020278$
23. Royet J, Gupta D, Dziarski R. Peptidoglycan recognition proteins: modulators of the microbiome and inflammation. Nat Rev Immunol. (2011) 11:837-51. doi: 10.1038/nri3089

24. Collins AR. Carotenoids and genomic stability. Mutat Res. (2001) 475:21-8. doi: 10.1016/S0027-5107(01)00071-9

25. Burri BJ. Carotenoids and gene expression. Nutrition. (2000) 16:577-8. doi: 10.1016/S0899-9007(00)00248-3

26. Tan KS, Zhang B, Ma H, Li S, Zheng H. Oxidative stress responses of golden and brown noble scallops Chlamys nobilis to acute cold stress. Fish Shellfish Immunol. (2019) 95:349-56. doi: 10.1016/j.fsi.2019.10.047

27. Tan KS, Leng X, Zhao Y, Liu H, Cheng D, Ma H, et al. Amino acid variations in polymorphic noble scallops, Chlamys nobilis. J Food Process Preserv. (2019) 43:e14262. doi: 10.1111/jfpp.14262

28. Tan KS, Zhang H, Liu H, Cheng D, Ye T, Ma H, et al. Enhancing lipid nutritional quality of oysters by hybridization between Crassostrea gigas and C. angulata. Aquacult Res. (2019) 50: 3776-82. doi: 10.1111/are.14340

29. Tan KS, Liu H, Ye T, Ma H, Li S, Zheng H. Growth, survival and lipid composition of Crassostrea gigas, C. angulata and their reciprocal hybrids cultured in southern China. Aquaculture. (2019) 516:734524. doi: 10.1016/j.aquaculture.2019.734524

30. Tan KS, Ma H, Li S, Zheng H. Bivalves as future source of sustainable natural omega-3 polyunsaturated fatty acids. Food Chem. (2019). doi: 10.1016/j.foodchem.2019.125907

31. Tan KS, Ransangan J. Dredging-induced shell damages to hard clam (Meretrix meretrix): a Malaysian case study. Aquat Living Resour. (2019) 32:1. doi: 10.1051/alr/2018025

32. Tan KS, Zheng HP. Climate change and bivalve mass mortality in temperate regions. In: de Voogt WP, editor. Reviews of Environmental Contamination and Toxicology. New York: Springer (2019). p. 109-29. doi: 10.1007/398_2019_31

33. Tan KS, Zheng H. Ocean acidification and adaptive bivalve farming. Sci Total Environ. (2019) 701:134794. doi: 10.1016/j.scitotenv.2019.134794

34. Tan KS, Ransangan J. Extrinsic factors and marine bivalve mass mortalities: an overview. J Shellfish Res. (2019) 38:1-10. doi: 10.2983/035.038.0202

35. Zhang $\mathrm{H}$, Cheng $\mathrm{D}$, Liu $\mathrm{H}$, Zheng $\mathrm{H}$. Differential responses of a thioredoxin-like protein gene to vibrio parahaemolyticus challenge in the noble scallop Chlamys nobilis with different total carotenoids content. Fish Shellfish Immunol. (2018) 72:377-82. doi: 10.1016/j.fsi.2017. 11.020

36. Zhang Q, Lu YQ, Zheng HP, Liu HL, Li SK. Differential immune response of vitellogenin gene to Vibrio anguillarum in noble scallop Chlamys nobilis and its correlation with total carotenoid content. Fish Shellfish Immunol. (2016) 50:11-5. doi: 10.1016/j.fsi.2016.01.001

37. Lu Y, Zheng H, Zhang H, Yang J, Wang Q. Cloning and differential expression of a novel toll-like receptor gene in noble scallop Chlamys nobilis with different total carotenoid content. Fish Shellfish Immunol. (2016) 56:229-38. doi: 10.1016/j.fsi.2016.07.007

38. Han J, Lu Y, Zheng H, Liu H, Deng H, Zhang B. Differential expression of CuZnSOD gene under low temperature stress in noble scallop Chlamys nobilis with different carotenoid content. Fish Shellfish Immunol. (2016) 54:30-9. doi: 10.1016/j.fsi.2016.03.160

39. Cornet S, Biard C, Moret Y. Is there a role for antioxidant carotenoids in limiting self-harming immune response in invertebrates? Biol Lett. (2007) 3:284-8. doi: 10.1098/rsbl.2007.0003

40. Liaaen-Jensen S. Carotenoids in food chain. In: Britton G, Liaaen-Jensen S, Pfander, H, editors. Carotenoids: Biosynthesis and Metabolism. Basel: Birkhäuser (1998). p. 359-71.

41. Liaaen-Jensen S. Marine carotenoids-Selected topics. $N$ J Chem. (1990) 14:747-59.

42. Matsuno T. Aquatic animal carotenoids. Fishery Sci. (2001) 67:771-89. doi: 10.1046/j.1444-2906.2001.00323.x

43. Matsuno T. Animal carotenoids. In: Krinsky, NI, Mathews-Roth, MM, Taylor, RF, editors. Carotenoids Chemistry and Biology. New York, NY: Plenum Press (1989). p. 59-74. doi: 10.1007/978-1-4613-0849-2_4

44. Matsuno T, Hirao S. Marine carotenoids. In: Ackman, RG, editor. Marine Biogenic Lipids, Fats, and Oils. Boca Raton, FL: CRC Press (1989) 1:251-388.

45. Cheng D, Liu H, Zhang H, Tan KS, Ye T, Li S, et al. Differential expression of HSP70 gene between golden and brown noble scallops Chlamys nobilis 
under heat stress and bacterial challenge. Fish Shellfish Immunol. (2019) 94:924-33. doi: 10.1016/j.fsi.2019.10.018

46. Wang N, Yang J, Zhang H, Tan KS, Liu H, Li S, et al. Differential responses to low salinity on gene expression, physiological and biochemical indexes between the golden and brown noble scallops Chlamys nobilis. Aquac Res. (2019) 51, 316-25. doi: 10.1111/are.14377

47. Zhang HK, Cheng DW, Tan KS, Ye T, Li SK, Ma HY, et al. Identification of two ferritin genes and their expression profiles in response to bacterial challenge in noble scallop Chlamys nobilis with different carotenoids content. Fish Shellfish Immunol. (2019) 88:9-16. doi: 10.1016/j.fsi.2019. 02.051

48. Dhinaut J, Balourdet A, Teixeira M, Chogne M, Moret Y. A dietary carotenoid reduces immunopathology and enhances longevity through an immune depressive effect in an insect model. Sci Rep. (2017) 7:12429. doi: 10.1038/s41598-017-12769-7

49. Babin A, Saciat C, Teixeira M, Troussard JP, Motreuil S, Moreau J. et al. Limiting immunopathology: interaction between carotenoids and enzymatic antioxidant defences. Dev Comp Immunol. (2015) (2015) 49:27881. doi: $10.1016 /$ j.dci.2014.12.007

50. Gostyukhina OL, Soldatov AA, Golovina IV, Borodina AV. Content of carotenoids and the state of tissue antioxidant enzymatic complex in bivalve mollusc Anadara inaequivalvis Br. Comp Ontog Biochem. (2011) 48:542-7. doi: $10.1134 / \mathrm{s} 0022093013030055$

51. Astley SB, Hughes DA, Wright AJ, Elliott RM, Southon S. DNA damage and susceptibility to oxidative damage in lymphocytes: effects of carotenoids in vitro and in vivo. Br J Nutr. (2004) 91:53-61. doi: 10.1079/BJN20031028

52. Sulik P, Klimek M, Talik P, Kuruk J, Morgan AJ, Plytycz B. Searching for external sources of the riboflavin stored in earthworm eleocytes. Invert Surv J. (2012) 9:169-77.

53. Plytycz B, Kielbasa E, Grebosz A, Duchnowski M, Morgan AJ. Riboflavin mobilization from eleocyte stores in the earthworm dendrodrilus rubidus inhabiting aerially-contaminated $\mathrm{Ni}$ smelter soil. Chemosphere. (2010) 81:199-205. doi: 10.1016/j.chemosphere.2010.06.056

54. Lemaitre B, Hoffmann J. The host defense of Drosophila melanogaster. Annu Rev Immunol. (2007) 25:697-743. doi: 10.1146/annurev.immunol.25.022106.141615

55. Hoffmann JA. The immune response of Drosophila. Nature. (2003) 426:33-8. doi: 10.1038/nature02021

56. Ratcliffe NA, Rowley AF, Fitzgerald SW, Rhodes CP. Invertebrate immunity: basic concepts and recent advances. Int Rev Cytol. (1985) 97:183-350. doi: 10.1016/S0074-7696(08)62351-7

57. Bachere E, Gueguen Y, Gonzalez M, de Lorgeril J, Garnier J, Romestand B. Insights into the anti-microbial defense of marine invertebrates: the penaeid shrimps and the oyster Crassostrea gigas. Immunol Rev. (2004) 198:149-68. doi: 10.1111/j.0105-2896.2004.00115.x

58. Libert S, Chao YF, Chu XW, Pletcher SD. Trade-offs between longevity and pathogen resistance in Drosophila melanogaster are mediated by NF kappa B signalling. Aging Cell. (2006) 6:533-43. doi: 10.1111/j.1474-9726.2006.00251.x

59. Stramer B, Wood W, Galko MJ, Redd MJ, Jacinto A, Parkhurst SM, et al. Live imaging of wound inflammation in Drosophila embryos reveals key roles for small GTPases during in vivo cell migration. J Cell Biol. (2005) 168:567-73. doi: $10.1083 /$ jcb. 200405120

60. Matova N, Anderson KV. Rel/NF-_B double mutants reveal the cellular immunity is central to Drosophila host defense. Proc Natl Acad Sci USA. (2006) 103:16424-9. doi: 10.1073/pnas.0605721103

61. Ayres JS, Schneider DS. A signaling protease required for melanization in Drosophila affects resistance and tolerance of infections. PLoS Biol. (2008) 6:2764-73. doi: 10.1371/journal.pbio.0060305

62. Alijagic A, Gagilo D, Napodano E, Russo R, Costa C, Benada O, et al. Titanium dioxide nanoparticles temporarily influence the sea urchin immunological state suppressing inflammatory-relate gene transcription and boosting antioxidant metabolic activity. J Hazardous Mater. (2020) 384:121389. doi: 10.1016/j.jhazmat.2019.121389

63. Alijagic A, Benada O, Kofronova O, Cigna D, Pinsino A. Sea urchin extracellular proteins design a complex protein corona on titanium dioxide nanoparticle surface influencing immune cell behavior. Front Immunol. (2019) 10:2261. doi: 10.3389/fimmu.2019.02261
64. Pinsino A, Russo R, Bonaventura R, Brunelli A, Marcomini A, Matranga V. Titanium dioxide nanoparticles stimulate sea urchin immune cell phagocytic activity involving TLR/p38 MAPK-mediated signalling pathway. Sci Rep. (2015) 5:14492. doi: 10.1038/srep14492

65. Gerdol M. Immune-related genes in gastropods and bivalves: a comparative overview. Invert Surv J. (2017) 14:103-18.

66. Nish S, Medzhitov R. Host defense pathways: role of redundancy and compensation in infectious disease phenotypes. Immunity. (2011) 34:62936. doi: 10.1016/j.immuni.2011.05.009

67. Eggert H, Diddens-de Buhr MF, Kurtz J. A temperature shock can lead to trans-generational immune priming in the red flour beetle, Tribolium castaneum. Ecol Evol. (2015) 5:1318-26. doi: 10.1002/ece 3.1443

68. Smith LC, Lun CM. The SpTransformer gene family (FormerlySp185/333) in the purple sea urchin and the functional diversity of the antipathogen rSpTransformer-E1 protein. Front Immunol. (2017) 8:725. doi: $10.3389 /$ fimmu.2017.00725

69. Fiedor J, Burda K. Potential role of carotenoids as antioxidants in human health and disease. Nutrients. (2014) 6:466-8. doi: 10.3390/nu6020466

70. McGraw KJ, Ardia DR. Carotenoids, immunocompetence, and the information content of sexual colors- an experimental test. Am Nat. (2003) 162:704-12. doi: 10.1086/378904

71. Bolin AP, Macedo RC, Marin DP, Barros MP, Otton R. Astaxanthin prevents in vitro auto-oxidative injury in human lymphocytes. Cell Biol Toxicol. (2010) 26:457-67. doi: 10.1007/s10565-010-9156-4

72. Krinsky NI, Johnson EJ. Carotenoid actions and their relation to health and disease. Mol Aspects Med. (2005) 26:459-516. doi: 10.1016/j.mam.2005.10.001

73. Pike TW, Blount JD, Metcalfe NB, Lindstrom J. Dietary carotenoid availability and reproductive effort influence the age-related decline in performance. Behav Ecol. (2010) 21:1048-53. doi: 10.1093/beheco/arq102

74. Zheng H, Zhang T, Sun Z, Liu W, Liu H. Inheritance of shell colours in the noble scallop Chlamys nobilis, (Bivalve: Pectinidae). Aquacult Res. (2013) 44:1229-35. doi: 10.1111/j.1365-2109.2012.03124.x

75. Liu $\mathrm{H}$, Zheng $\mathrm{H}$, Zhang $\mathrm{H}$, Deng L, Liu $\mathrm{W}$, Wang $\mathrm{S}$, et al. A de novo transcriptome of the noble scallop, Chlamys nobilis, focusing on mining transcripts for carotenoid-based coloration. BMC Genomics. (2015) 16:44. doi: 10.1186/s12864-015-1241-x

76. Xue YP. Roles of the carotenoid binding protein StAR-like-3 in carotenoids accumulation in the noble scallop Chlamys nobilis (Msc Thesis). Shantou University, Shantou, China (2018).

77. Porrini M, Riso P. Lymphocyte lycopene concentration and DNA protection from oxidative damage is increased in women after a short period of tomato consumption. J Nutr. (2000) 130:189-92. doi: 10.1093/jn/130.2.189

78. Vílchez C, Forján E, Cuaresma M, Bédmar F, Garbayo I, Vega JM. Marine carotenoids: biological functions and commercial applications. Mar Drugs. (2011) 9:319-33. doi: 10.3390/md9030319

79. Schleder DD, Kayser M, Suhnel S, Ferreira JF, Rupp GS, Barracco MA. Evaluation of hemato-immunological parameters during the reproductive cycle of the scallop Nodipecten nodosus in association with a carotenoid-enriched diet. Aquaculture. (2008) 280:256-63. doi: 10.1016/j.aquaculture.2008.05.001

80. Miyashita K. Function of marine carotenoids. Forum Nutrition. (2009) 6:136-46. doi: $10.1159 / 000212746$

81. Ashley NT, Weil ZM, Nelson RJ. Inflammation: mechanisms, costs, and natural variation. Аnnu Rev Ecol Evol Syst. (2012) 43:385-406. doi: 10.1146/annurev-ecolsys-040212-092530

82. Wang SY, Jiao H. Scavenging capacity of berry crops on superoxide radicals, hydrogen peroxide, hydroxyl radicals, and singlet oxygen. J Agric Food Chem. (2000) 48:5677-84. doi: 10.1021/jf000766i

83. Kehrer JP. Free radicals as mediators of tissue injury and disease. Critic Rev Toxicol. (1993) 23:21-48. doi: 10.3109/10408449309104073

84. Pawelec G, Goldeck D, Derhovanessian E. Inflammation, ageing and chronic disease. Curr Opin Immunol. (2014) 29:23-8. doi: 10.1016/j.coi.2014.03.007

85. Licastro F, Candore G, Lio D, Porcellini E, Colonna-Romano G, Franceschi $\mathrm{C}$, et al. Innate immunity and inflammation in aging: a key for understanding age-related diseases. Immun Ageing. (2005) 2:8-22. doi: $10.1186 / 1742-4933-2-8$ 
86. Finch CE, Crimmins EM. Inflammatory exposure and historical changes in human life-spans. Science. (2004) 305:1736-9. doi: 10.1126/science.10 92556

87. Mruk DD, Silvestrini B, Mo M, Chenga CY. Antioxidant superoxide dismutaseda review: its function, regulation in the testis, and role in male fertility. Contraception. (2002) 65:305-11. doi: 10.1016/S0010-7824(01)00320-1

88. Fink RC, Scandalios JG. Molecular evolution and structurefunction relationships of the superoxide dismutase gene families in angiosperms and their relationship to other eukaryotic and prokaryotic superoxide dismutases. Arch Biochem Biophys. (2002) 399:19-36. doi: 10.1006/abbi.2001.2739

89. Shimidzu N, Goto M, Miki W. Carotenoids as singlet oxygen quenchers in marine organisms. Fish Sci. (1996) 62:134-7. doi: 10.2331/fishsci.62.134

90. Yeum KJ, Aldini G, Russell RM, Krinsky NI. Antioxidant/Pro-oxidant actions of carotenoids, carotenoids. In: Britton G, Liaaen-Jensen S, Pfander H, editors. Nutrition and Health. Basel: Birkhauser Verlag (2009). p. 235-62. doi: 10.1007/978-3-7643-7501-0_12

91. Tsushima M, Kawakami T, Mine M, Matsuno T. The role of carotenoids in the development of the sea urchin Pseudocentrotus depressus. Invert Reprod Dev. (1997) 32:149-53. doi: 10.1080/07924259.1997.96 72616

92. Kawakami T, Tsushima M, Katabami Y, Mine M, Ishida A, Matsuno T. Effect of $\beta, \beta$-carotene, $\beta$-echinenone, astaxanthin, fucoxanthin, vitamin $\mathrm{A}$ and vitamin $\mathrm{E}$ on the biological defence of the sea urchin Pseudocentrotus depressus. J Exp Mar Biol Ecol. (1998) 226:165-74. doi: 10.1016/S0022-0981(97)00236-0

93. Bao YB, Li L, Xu F, Zhang GF. Intracellular copper/zinc superoxide dismutase from bay scallop Argopecten irradians: its gene structure, mRNA expression and recombinant protein. Fish Shellfish Immunol. (2009) 27:21020. doi: 10.1016/j.fsi.2009.04.005

94. Lubrano V, Balzan S. Enzymatic antioxidant system in vascular inflammation and coronary artery disease. World J Exp Med. (2015) 5:218-24. doi: 10.5493/wjem.v5.i4.218

95. Kumar V, Pillai BR, Sahoo PK, Mohanty J, Mohanty S. Effect of dietary astaxanthin on growth and immune response of Giant freshwater prawn Macrobrachium rosenbergii (de man). Asian Fishery Soc. (2009) 22:61-9. doi: 10.1111/j.1749-7345.2009.00300.x

96. Angeles IP Jr, Chien Y-H, Yambot AV. Effect of infected astaxanthin on survival, antioxidant capacity, and immune response of the giant freshwater prawn Macrobrachium rosenbergii (De Man, 1879) challenged with Lactococcus garvieae. J Shellfish Res. (2009) 28:931-7. doi: 10.2983/035.028.0424

97. Cheng D, Liu H, Zhang H, Tan KS, Ye T, Li S, et al. Effects of thermal stress on mortality and HSP90 expression levels in the noble scallops Chlamys nobilis with different total carotenoids content. Cell Stress Chaperones. (2019). doi: 10.1007/s12192-019-01052-5

98. Arnér ES, Holmgren A. Physiological functions of thioredoxin and thioredoxin reductase. FEBS J. (2000) 267:6102-9. doi: 10.1046/j.1432-1327.2000.01701.x

99. Cheng S, Li C, Wang Y, Yang L, Chang Y. Characterization and expression analysis of a thioredoxin-like protein gene in the sea cucumber Apostichopus japonicas. Fish Shellfish Immunol. (2016) 58:165-73. doi: 10.1016/j.fsi.2016.08.061

100. Revathy KS, Umasuthan N, Lee Y, Whang I, Kim HC, Lee J. Cytosolic thioredoxin from Ruditapes philippinarum: molecular cloning, characterization, expression and DNA protection activity of the recombinant protein. Dev Comp Immunol. (2012) 36:85-92. doi: 10.1016/j.dci.2011. 06.006

101. Garcia-Orozco KD, Sanchez-Paz A, Aispuro-Hernandez E, Gomez-Jimenez S, Lopez-Zavala A, Araujo-Bernal S, et al. Gene expression and protein levels of thioredoxin in the gills from the white leg shrimp (Litopenaeus vannamei) infected with two different viruses: the WSSV or IHHNV. Fish Shellfish Immunol. (2012) 32:1141-7. doi: 10.1016/j.fsi.2012.03.020

102. Pushpamali WA, De Zoysa M, Kang HS, Oh CH, Whang I, Kim SJ, et al. Comparative study of two thioredoxin peroxidases from disk abalone (Haliotis discus discus): cloning, recombinant protein purification, characterization of antioxidant activities and expression analysis. Fish Shellfish Immunol. (2008) 24:294-307. doi: 10.1016/j.fsi.2007. 11.016

103. Chew BP, Park JS. Carotenoid action on the immune response. J Nutr. (2004) 134:257-61. doi: 10.1093/jn/134.1.257S

104. Matozzo V, Gagne F, Marin MG, Ricciardi F, Blaise C. Vitellogenin as a biomarker of exposure to estrogenic compounds in aquatic invertebrates: a review. Environ Int. (2008) 34:531-45. doi: 10.1016/j.envint.2007.09.008

105. Robinson R. For mammals, loss of yolk and gain of milk went hand in hand. PLoS Biol. (2008) 6:e77. doi: 10.1371/journal.pbio.0060077

106. Brooks JM, Wessel GM. The major yolk protein in sea urchins is a transferrin-like, iron binding protein. Dev Biol. (2002) 245:1-12. doi: 10.1006/dbio.2002.0611

107. Ando S, Hantano M.. Distribution of carotenoids in the eggs from four species of samonid. Comp Biochem Physiol. (1991) 99B:341-4.

108. Wu B, Liu ZH, Zhou LQ, Ji GD, Yang AG. Molecular cloning, expression, purification and characterization of vitellogenin in scallop Patinopecten yessoensis with special emphasis on its antibacterial activity. Dev Comp Immunol. (2015) 49:249-58. doi: 10.1016/j.dci.2014.12.004

109. Ni DJ, Song LS, Gao Q, Wu LT, Yu YD, Zhao JM, et al. The cDNA cloning and mRNA expression of cytoplasmic $\mathrm{Cu}, \mathrm{Zn}$ superoxide dismutase (SOD) gene in scallop Chlamys farreri. Fish Shellfish Immunol. (2007) 23:1032-42. doi: 10.1016/j.fsi.2007.04.008

110. Wei X, Yang J, Yang D, Xu J, Liu X, Yang J, et al. Molecular cloning and mRNA expression of two peptidoglycan recognition protein (PGRP) genes from mollusk Solen grandis. Fish Shellfish Immunol. (2012) 32:178-85. doi: 10.1016/j.fsi.2011.11.009

111. Ong ST, Ho JZ, Ho B, Ding JL. Iron-withholding strategy in innate immunity. Immunobiology. (2006) 211:295-314. doi: 10.1016/j.imbio.2006.02.004

112. Shi H, Bencze KZ, Stemmler TL, Philpott CC. A cytosolic iron chaperone that delivers iron to ferritin. Science. (2008) 320:1207-10. doi: $10.1126 /$ science. 1157643

113. Chen G, Zhang C, Wang Y, Guo C, Sang F, Wang C. Identification and characterization of a ferritin gene involved in the immune defence response of scallop Chlamys farreri. Fish Shellfish Immunol. (2016) 55:1-9. doi: 10.1016/j.fsi.2016.04.128

114. Medzhitov R, Janeway CA Jr. Decoding the patterns of self and non-self by the innate immune system. Science. (2002) 296:298-300. doi: 10.1126/science. 1068883

115. Medzhitov R, Janeway CA Jr. Innate immunity. N Engl J Med. (2000) 343:338-44. doi: 10.1056/NEJM200008033430506

116. Beutler B, Jiang Z, Georgel P, Crozat K, Croker B, Rutschmann S, et al. Genetic analysis of host resistance: toll-like receptor signaling and immunity at large. Ann Rev Immunol. (2006) 24:353-89. doi: 10.1146/annurev.immunol.24.021605.090552

117. Hoshino K, Takeuchi O, Kawai T, Sanjo H, Ogawa T, Takeda Y, et al. Cutting edge: toll-like receptor 4 (TLR4)-deficient mice are hyporesponsive to lipopolysaccharide: evidence for TLR4 as the Lps gene product. J Immunol. (1999) 162:3749-52.

118. Coscia MR, Giacomelli S, Oreste U. Toll-like receptors: an overview from invertebrates to vertebrates. Invert Surv J. (2011) 8:210-26. doi: 10.3389/fimmu.2018.01523

119. Qiu LM, Song LS, Xu W, Ni DJ, Yu YD. Molecular cloning and expression of a toll receptor gene homologue from Zhikong Scallop, Chlamys farreri. Fish Shellfish Immunol. (2015) 22:451-66. doi: 10.1016/j.fsi.2006.05.003

120. Toubiana M, Gerdol M, Rosani U, Pallavicini A, Venier P, Roch P. Toll-like receptors and MyD88 adaptors in Mytilus: complete cds and gene expression levels. Dev Comp Immunol. (2013) 40:158-66. doi: 10.1016/j.dci.2013.02.006

121. Zhang LL, Li L, Zhang GF. A Crassostrea gigas toll-like receptor and comparative analysis of TLR pathway in invertebrates. Fish Shellfish Immunol. (2011) 30:653-60. doi: 10.1016/j.fsi.2010.12.023

122. Mateo DR, Greenwood SJ, Araya MT, Berthe FC, Johnson GR, Siah A Differential gene expression of gamma-actin, Toll-like receptor 2 (TLR-2) and interleukin-1 receptor-associated kinase 4 (IRAK-4) in Mya arenaria haemocytes induced by in vivo infections with two Vibrio splendidus strains. Dev Comp Immunol. (2010) 34:710-4. doi: 10.1016/j.dci.2010.02.006

123. Cornet V, Henry J, Corre E, Le Corguill G, Zatylny-Gaudin EC. The Toll/NFkappaB pathway in cuttlefish symbiotic accessory nidamental gland. Dev Comp Immunol. (2015) 53:42-6. doi: 10.1016/j.dci.2015.06.016 
124. Goodson MS, Kojadinovic M, Troll JV, Scheetz TE, Casavant TL, Soares MB, et al. Identifying components of the NF-kappa B pathway in the beneficial Euprymna scolopes-Vibrio fischeri light organ symbiosis. Appl Environ Microbiol. (2005) 71:6934-46. doi: 10.1128/AEM.71.11.6934-6946.2005

125. Cerenius L, Lee BL, Soderhall K. The proPO-System: pros and cons for its role in invertebrate immunity. Trends Immunol. (2008) 29:263-71. doi: 10.1016/j.it.2008.02.009

126. Leclerc V, Reichhart JM. Prophenoloxidase activation is not required for survival to microbial infections in Drosophila. EMBO Rep. (2006) 7:231-5. doi: 10.1038/sj.embor.7400592

127. Cerenius L, Söderhäll K. The prophenoloxidase-activating system in invertebrates. Immunol Rev. (2004) 198:116-26. doi: 10.1111/j.0105-2896.2004.00116.x

128. Girón-Pérez MI. Relationships between innate immunity in bivalve molluscs and environmental pollution. Information Syst J. (2010) 7:149-56.

129. Wang Q, Wang J, Wang G, Wu C, Li J. Molecular cloning, sequencing, and expression profiles of heat shock protein 90 (HSP90) in Hyriopsis cumingii, exposed to different stressors: temperature, cadmium and Aeromonas hydrophila. Aquacult Fisheries. (2017) 2:59-66. doi: 10.1016/j.aaf.2017. 03.001

130. Pinsino A, Turturici G, Sconzo G, Geraci F. Rapid changes in heatshock cognate 70 levels, heat-shock cognate phosphorylation state, heatshock transcription factor, and metal transcription factor activity levels in response to heavy metal exposure during sea urchin embryonic development. Ecotoxicology. (2011) 20:246-54. doi: 10.1007/s10646-010-0576-y

131. Kiang JG, Tsokos GC. Heat shock protein $70 \mathrm{kDa}$ : molecular biology, biochemistry, and physiology. Pharmacol Therap. (1998) 80:183-201. doi: 10.1016/S0163-7258(98)00028-X

132. Gao Q, Song L, Ni D, Wu L, Zhang H, Chang Y. cDNA cloning and mRNA expression of heat shock protein 90 gene in the haemocytes of Zhikong scallop Chlamys farreri. Comp Biochem Physiol Part B. (2007) 147:704-15. doi: 10.1016/j.cbpb.2007.04.010
133. Gao Q, Zhao J, Song L, Qiu L, Zhang H, Ni D. Molecular cloning, characterization and expression of heat shock protein 90 gene in the haemocytes of bay scallop Argopecten irradians. Fish Shellfish Immunol. (2008) 24:379-85. doi: 10.1016/j.fsi.2007.08.008

134. Choi YK, Jo PG, Choi CY. Cadmium affects the expression of heat shock protein 90 and metallothionein mRNA in the Pacific oyster, Crassostrea gigas. Comp Biochem Physiol Part C Toxicol Pharmacol. (2008) 147:286-92. doi: 10.1016/j.cbpc.2007.11.002

135. Zhang W, Wu C, Mai K, Chen Q, Xu W. Molecular cloning, characterization and expression analysis of heat shock protein 90 from Pacific abalone, Haliotis discus hannai Ino in response to dietary selenium. Fish Shellfish Immunol. (2011) 30:280. doi: 10.1016/j.fsi.2010.10.019

136. Liu T, Pan L, Cai Y, Miao J. Molecular cloning and sequence analysis of heat shock proteins 70 (HSP70) and 90 (HSP90) and their expression analysis when exposed to benzo(a)pyrene in the clam Ruditapes philippinarum. Gene. (2015) 555:108-18. doi: 10.1016/j.gene.2014.10.051

137. Strzałka K, Kostecka-Gugała A, Latowski D. Carotenoids and environmental stress in plants: significance of carotenoid-mediated modulation of membrane physical properties. Russian J Plant Physiol. (2003) 50:168-72. doi: 10.1023/A:1022960828050

Conflict of Interest: The authors declare that the research was conducted in the absence of any commercial or financial relationships that could be construed as a potential conflict of interest.

Copyright $\odot 2020$ Tan, Zhang, Lim, Ma, Li and Zheng. This is an open-access article distributed under the terms of the Creative Commons Attribution License (CC BY). The use, distribution or reproduction in other forums is permitted, provided the original author(s) and the copyright owner(s) are credited and that the original publication in this journal is cited, in accordance with accepted academic practice. No use, distribution or reproduction is permitted which does not comply with these terms. 